\title{
СІМЕЙНО-ПОБУТОВЕ НАСИЛЬСТВО ЯК КРИМІНОЛОГІЧНА ПРОБЛЕМА
}

Собко Г. М.

У науковій статmі досліджено сутність та юридичну природу сімейно-побутового насильства як механізму психічного насильства, що пригнічує волю особи. Розглянуто статистичні дані з приводу зростання насильства на соціально-побутовому рівні. Проаналізований ґендерний складник соціально-побутового насильства в сім'ї. Встановлені терміни, які вживаються у разі вчинення сімейно-побутового насильства. Зроблені пропозиції з удосконалення законодавства щодо насильства.

Ключові слова: насильство, кримінологічні дослідження, криміногенні фактори, побутовий злочин, злочинHicmb.

В научной статье исследована сущность и юридическая природа семейно-бытового насилия как механизма психического насилия, которое подавляет волю человека. Рассмотрены статистические данные о росте насилия на социально-бытовом уровне. Проанализирована гендерная составляющая социально-бытового насилия в семье. Onределены термины, которые употребляются при социально-бытовом насилии. Сделаны предложения по совершенствованию законодательства по насилию.

Ключевые слова: насилие, криминологические исследования, криминогенные факторы, бытовое преступление, nрестунность.

The scientific article investigates the nature and legal nature of domestic violence as a mechanism of mental violence that inhibits the will of the individual. The statistics on the increase of violence at the social and domestic level are considered. The gender component of domestic violence in the family is analyzed. Domestic violence, as a criminological problem, contains an endless variety of contradictory situations of economic, political, legal, methodological, ideological, psychological, medical, pedagogical and other nature. These circumstances form the idea of analysis and systematization of knowledge about nature, mechanisms of formation and functioning, neutralization of domestic violence, and in the final form - the development of criminological theory of domestic violence. The study of the practice of combating domestic crime revealed a number of significant points that reduce the effectiveness of preventive work. The obstacle is not only the particular conservatism of everyday psychology, but also the unattainability or the extremely insufficient reach of family-household relations for purposeful educational work and social control. The motives for committing crimes in everyday life are largely generated by the intimate, purely personal nature of family relationships between spouses, close relatives. As a result, it is sometimes difficult to identify the point at which interference with people's personal lives is unacceptable. Here, it is often necessary to coordinate actions with the constitutional requirement for the inviolability of housing and the individual. In other words, the specifics of domestic relations limit the ability of police to intervene in domestic conflicts. There are also some difficulties in the process of detecting anomalous relationships in everyday life, as some of them occur in separate apartments, private homes, that is, in conditions of anonymity, with frequent forgiveness of the perpetrator of criminal acts of the perpetrator.
All this requires exceptional tact and high professionalism from the subjects of prevention, requires knowledge of the basics of psychology, pedagogy and family criminology.

At the same time, subjects of preventing domestic violence should effectively combine criminal and social-psychological measures.

Key words: violence, criminological research, criminogenic factors, domestic crime, crime.

Постановка проблеми та їі актуальність. Сімейно-побутове насильство посідає значне місце в структурі насильницької злочинності. У сімейних конфліктах воно виражається у вигляді заподіяння шкоди здоров'ю різного ступеня тяжкості або смерті. Слід визнати, що нині рівень знань про природу сімейно-побутового насильства недостатній, що зумовлює необхідність проведення розгорнутих комплексних (із застосуванням системного підходу) соціально-психологічних, кримінологічних і медико-психіатричних досліджень цієї сфери, присвячених як практичним, так і теоретичним питанням. Теоретичні дослідження мають бути спрямовані на системне вивчення чинників, що породжують сімейні та побутові конфлікти і зумовлюють їх переростання в різні варіанти злочинної поведінки. Прикладна сторона має відповідати розробці системи превентивних заходів, покликаних ліквідувати або нейтралізувати дію криміногенних факторів, що породжують насильство в сім'ї.

Сімейно-побутове насильство як кримінологічна проблема містить нескінченне різноманіття суперечливих ситуацій економічного, політичного, правового, методологічного, світоглядного, психологічного, медичного, педагогічного та іншого характеру. Ці обставини формують ідею аналізу і систематизації знань про природу, механізми формування і функціонування, нейтралізації побутового насильства, а в завершеному вигляді - розробку кримінологічної теорії сімейно-побутового насильства.

Аналіз останніх досліджень і публікацій. 3 кожним роком шокуюча статистика щодо насильства вдома невпинно зростає. У 90\% випадків - це насильство чоловіків стосовно жінок, проте лише $10 \%$ повідомлень про насильство в сім'ї доходить до правоохоронних органів. За офіційними даними, у 2017 році близько 600 жінок загинули від рук насильників [1].

3 початку 2018 року на адресу Уповноваженого Верховної Ради України з прав людини надійшло 15 повідомлень стосовно вчинення домашнього насильства, від якого постраждали 13 жінок, 5 дітей і 2 чоловіки. За вказаними випадками Уповноваженим було відкрито провадження та надіслано відповідні акти реагування до суб'єктів, що здійснюють заходи у сфері запобігання та протидії домашньому насильству [2].

Собко Г. М., 2019 
Найчастіше спочатку проявляється психічне насильство, яке в певний момент доповнюється різними за ступенем тяжкості фізичними діями, а потім воно може перерости у фізичне або сексуальне насильство.

Домашнє насильство носить циклічний характер.

Мета цієї статті - проаналізувати прояви психічного насильства на соціально-побутовому рівні як кримінологічної категорії.

Виклад основного матеріалу. Під сімейно-побутовим насильством можна розуміти діяння як злочинні, так і такі, що виходять за межі поняття «злочин». Якщо розуміти під сімейно-побутовим насильством тільки діяння, які підпадають під визначення злочинних, то практично неможливо буде вирішити цю проблему. Необхідно послідовно вивчати умови формування його механізму, детермінованість різних причин і умов, комплексність підходу, системність аналізу.

«Коли поринаєш у світ насильства і жорстокості, пише А. Приставкін, - на власні очі бачиш те, що все починається з сім'ї і побуту <...>. Здається, що читаєш одну і ту ж історію: зустрілися - випили - сварка - побої вбивство. Чоловік убив дружину - втопив у власному колодязі. Дружина чоловіка зарізала кухонним ножем. Дочка душить мати. Син ріже батька. Брат убиває брата. Нескінченне знищення один одного, а в результаті 30 тис. убивств на рік, не рахуючи заподіяння тяжкої шкоди здоров'ю, що часто закінчується смертю потерпілого. Сімейні конфлікти - сімейні злочини» [3, с. 99].

Особливістю сімейних відносин $є$ не тільки те, що вони засновані на родинних зв'язках. У сім'ї формуються, створюються і підтримуються матеріальні і духовні потреби людини, певні традиції, відбувається становлення особистості. Однак при цьому нерідко виникають і різні протиріччя, найбільш гострі з яких за певного збігу обставин переходять у конфлікти, а останні часом переростають у посягання на об'єкти, що охороняються. Безсумнівно, сім'я, яку роздирають наявні конфлікти, не в змозі грати роль центру психологічного захисту особистості, в якому вона знаходить заспокоєння і відпочинок, не може виконувати функції виховання і соціального контролю. Насильство в сім'ї завдає нищівного удару дітям, рани від якого не гояться ніколи і своєю чергою можуть породити їхні жорстокі дії, і в цілому завдає непоправної моральної шкоди суспільству [4, с. 194].

Побут у філософській та соціологічній літературі розуміється як невиробнича сфера життя, що безпосередньо пов'язана зі споживанням матеріальних і духовних цінностей, формами і способами цього споживання. Це невиробнича сфера людського буття, невіддільна від інших сфер життєдіяльності особистості: повсякденний уклад життя, заснований на звичному розпорядку, традиціях, що встановилися між людьми [5, с. 13].

Таким чином, побут є однією з основних форм суспільного життя, де формується і отримує виховання людина, задовольняються ії життєво важливі потреби, розкриваються різноманітні повсякденні відносини. Звідси можна зробити висновок, що побут являє собою сукупність невиробничих відносин сімейно-побутового, комунально-побутового і виробничо-побутового характеру, що виникають з приводу задоволення матеріальних і духовних потреб людини [6, с. 14].

3 кримінологічної точки зору велике значення має визначення поняття і структурних елементів, що харак- теризують «побут». Ми повністю підтримуємо думку Г. Панфілова про зміст поняття «побутовий злочин» і вважаємо, що необхідно виділити дві основні спрямованості побутової сфери:

1) особистісно-побутову (сім'я, спорідненість, дружба, товариство, сусідство);

2) суспільно-побутову (виробничий і громадський побут, побутові послуги) [7, с. 53].

Основною формою спільності в побуті $\epsilon$ сім'я. А головним елементом внутрісімейного спілкування слід виділити шлюбно-сімейні відносини, які мають правове регулювання.

Отже, визначаючи сукупність тих суспільних відносин, які включає в себе сімейно-побутова сфера, можна зробити висновок, що такими $є$ особистісні звичайні відносини між членами сім'ї, родичами, сусідами, знайомими, пов'язані зі споживанням невиробничих матеріальних і духовних цінностей і засновані на звичному розпорядку, традиціях і відносинах, що встановилися між людьми.

Проведене нами дослідження свідчить про те, що в сучасному суспільстві поширюється і закріплюється уявлення про безсилля закону, безкарність злочинців, правове свавілля. Все це формує у людей відчуття незахищеності, запеклості, причому практично в будьяких соціальних шарах і групах суспільства незалежно від їх статусу і матеріального становища.

Більшість людей вважають, що держава безсила перед широко поширеним побутовим насильством. Внаслідок цього останнє стало звичним і навіть «нормальним» явищем для багатьох сімей.

Напруга - окремі спалахи образ. Жінки зазвичай реагують спокійно, намагаючись розрядити обстановку або намагаються захистити себе. 3 ростом напруги здатності жінки балансувати стають усе слабкішими.

Гостре насильство - сплеск напруги в самій негативній формі. Напади гніву настільки сильні, що кривдник не може заперечувати їх існування. Можлива реалізація акту насильства над жертвою.

Вирішення ситуації. $€$ кілька варіантів вирішення: розрив відносин, притягнення насильника до кримінальної відповідальності, врегулювання конфлікту мирним шляхом.

Особливе значення в механізмі криміногенних факторів насильства мають причини, які визначаються біоi морально-психологічними властивостями людини, індивідуальними фізіологічними особливостями, системою моральних цінностей.

Безкарність сімейного мучителя, страх за своє життя і життя своїх дітей, розчарування, безвихідь орієнтують жінок на самостійні способи захисту. Дослідження Ф. Сафуанова підтверджують, що жіноча кримінальна агресія - це переважно агресія, зумовлена не агресивністю як властивістю особистості, а взаємодією з психотравмуючим впливом [8, с. 150-152].

Насильницька злочинність у родині, будучи зумовленою загальними причинами злочинності, має свої особливості, що істотно відрізняють їі як від загальної побутової злочинності, так і від злочинності загалом. Вона зумовлена цілим комплексом причин, які необхідно розглядати тільки в контексті конкретних соціальних умов життя. Негативні соціальні, демографічні, економічні, політичні, психологічні, моральні, культурні та інші явища, що характеризують життя 
сучасного суспільства, - основні детермінанти зазначеної злочинності. Загалом причини насильства в сім'ї можуть бути поділені на дві групи.

Перша - соціально-економічна група - включає в себе такі основні причини, як зростання безробіття, бідності, пияцтва i наркоманії, різке розшарування суспільства на бідних і багатих. Сім'я не може не відчувати на собі тяготи і проблеми суспільства, всі його матеріальні і духовні труднощі, не відображати в собі сучасні процеси економічної невлаштованості і тривожних очікувань. Тому значна частина проявів насильства пов'язана 3 невирішеністю матеріального забезпечення сім'ї, насамперед інвалідів та людей похилого віку, з житловими проблемами, невлаштованістю мігрантів і біженців. Друга - соціально-психологічна група - включає в себе цілий комплекс причин, зумовлених особливостями особистості, стану соматичного і психічного здоров'я, сформованих традицій сімейних відносин. Так, насильство між подружжям (співмешканцями) зазвичай стимулюється ревнощами і помстою за дії або уявні образи, а також переживаннями, пов'язаними з сексуальною незадоволеністю. Насильство між ними може породжуватися суперництвом за верховенство в родині.

Натепер сприятливим ґрунтом для насильницької злочинності в сім'ї залишається неблагополучне маргінальне середовище проживання з потворним побутом, убогим і спотвореним дозвіллям. У зв'язку з інтенсивним розпадом сімей збільшується частина люмпенізованих, десоціалізованих членів суспільства як у дорослому, так і в молодіжному середовищі. Соціальна напруженість виступає живильним ґрунтом повсякденних конфліктів у сім'ях. Падіння моральності і духовної культури всього суспільства відбивається в мікрогрупах, у тому числі і в сім'ї, де відносини набувають різних характеристик: взаємної неповаги, жорстокості, нетерпіння, цинізму. Соціальна і географічна мобільність населення часто впливає на старше покоління, яке залишається без повноцінної родинної підтримки в старості.

Проблема насильства в сім'ї - частина проблеми культури, рівності статей, соціально-економічної та правової захищеності особистості в сучасному суспільстві. Сукупність наведених обставин свідчить про високу соціальну небезпеку зростання насильства в сім'ї, необхідність прийняття адекватних заходів, що поєднують у собі примус, із заходами підтримки і допомоги, в тому числі матеріальної і медичної, сім'ям «підвищеного ризику», в яких в тій чи іншій формі може проявитися насильство, перш за все стосовно дітей. Безумовно, об'єктом домашнього насильства можуть бути будь-які члени сім'ї. Прийнято виділяти три типи сімейної жорстокості: з боку батьків стосовно дітей, з боку одного з подружжя стосовно іншого, з боку дітей та онуків стосовно інших родичів. На жаль, найбільш часто в таких ситуаціях жертвами стають діти як найбільш вразлива і незахищена частина суспільства.

Факти жорстокого поводження з дітьми в сім’ї, в дитячих установах часто ховаються. Знаючи про такі факти, педагоги, медичні та інші працівники нерідко виявляють байдужість до долі дитини і не повідомляють про них ні органам опіки та піклування, ні правоохоронним органам. Багато з дітей перебувають у стані постійної напруги, у них переважає почуття страху i невпевненості. Це дає змогу припустити, що вони постійно відчувають або зазнавали коли-небудь насильство над собою. Жорстоке поводження батьків з дітьми може виражатися: у неправомірному фізичному і психічному впливі, а іноді і в прямому насильстві; недозволених прийомах виховання; приниженні честі та гідності; залишенні в безпорадному стані; залишенні без їжі і води; замиканні в окреме приміщення і позбавлення свободи переміщення дитини в житлі; виштовхуванні на вулицю. На думку Н. Машинського, під насильством у сім'ї проти неповнолітніх (дітей) слід розуміти активний свідомий акт поведінки батьків, опікуна чи піклувальника, який здійснюється в протиріччя правам і законним інтересам неповнолітнього, заподіює або здатний заподіяти шкоду його фізичному і (або) психічному розвитку $[9$, с. 33].

Психологи відзначають, що, випробувавши фізичне насильство, дитина виробляє агресивну модель поведінки. Якщо вона і навчилася придушувати і заперечувати свої почуття, це може привести до депресії і спровокувати саморуйнівну поведінку, оскільки вираз гніву стосовно того, що сталося фізичне насильство і особи, яка вчинила фізичне насильство над нею, буває занадто небезпечним або безрезультатним. Тому гнів дитини звертається всередину, проти неї самої, викликаючи депресії і ненависть до себе [10, с. 42-43].

Однак це зовсім не означає, що діти мають виховуватися без всяких обмежень. Ненасильницька комунікація ґрунтується на повазі з боку дорослих до особистості дитини, терпимості до дитячих почуттів і насамперед на повазі особистості дитини, прийняття іiї такою, якою вона $\epsilon$.

Резюмуючи викладене, звернемо увагу на те, що проблема насильства стосовно дітей стала особливо актуальною нині. У зв'язку з цим необхідне прийняття кардинальних заходів, що забезпечують перш за все безпеку дітей від злочинних посягань на їх нормальний фізичний і моральний розвиток. Такими заходами могли б бути не тільки вдосконалення законодавчої бази нашої держави в плані захисту дітей, а й створення спеціальних програм щодо боротьби з домашнім, шкільним, вуличним і іншими видами насильства стосовно дітей.

Висновки. Вивчення практики боротьби з сімейно-побутовою злочинністю виявило низку істотних моментів, які знижують ефективність проведеної попереджувальної роботи. Перешкодою $\epsilon$ не тільки особлива консервативність побутової психології, але і недосяжність або вкрай недостатня досяжність сімейно-побутових відносин для цілеспрямованої виховної роботи, соціального контролю. Мотиви скоєння злочинів у побуті значною мірою породжуються інтимним, суто особистим характером сімейних відносин між подружжям, близькими родичами. Внаслідок цього часом важко виявити ту грань, за якої втручання в особисте життя людей неприпустиме. Тут часто доводиться погоджувати дії з конституційною вимогою про недоторканність житла й особистості. Іншими словами, специфіка побутових відносин обмежує можливість міліції щодо втручання в побутові конфлікти. Певні труднощі $\epsilon$ і в самому процесі виявлення аномальних відносин у побуті, позаяк частина їх відбувається в окремих квартирах, приватних будинках, тобто в умовах анонімності, з частим прощенням потерпілим злочинних дій винного. Все це вимагає виняткового такту і високого 
професіоналізму від суб'єктів профілактики, передбачає знання ними основ психології, педагогіки і сімейної кримінології.

Загалом для підвищення ефективності попереджувальної діяльності державні та громадські структури мають комплексно планувати заходи, спрямовані на зміцнення сім'ї, поліпшення мікроклімату в ній, об'єднуючи при цьому зусилля всіх зацікавлених міністерств, органів влади і управління, державних і громадських організацій, використовуючи зарубіжний досвід. При цьому суб'єктам попередження сімейно-побутового насильства слід ефективно поєднувати заходи кримінально-правового і соціально-психологічного впливу.

1. Вживання заходів з проведення індивідуальної профілактики. Для іï ефективності необхідно проводити спеціальні семінари з підготовки співробітників органів внутрішніх справ для роботи з сімейно-побутовим насильством.

2. Розробка системи узгодженої протидії насильству в сфері сімейно-побутових відносин, яка поєднає зусилля правоохоронних органів, судів, соціальних служб, освітніх і медичних установ. При цьому має йтися не просто про якісь заходи, а про вироблення соціальної технології, що об'єднує діяльність представників різних структур і передбачає комплексне планування заходів, спрямованих на зміцнення сім'ї, поліпшення мікроклімату в ній, поєднання заходів загального та індивідуального попередження, вдосконалення практики за рахунок використання зарубіжного досвіду.

3. Залучення засобів масової інформації з метою пропаганди проблеми побутового насильства в сучасному суспільстві і формування масової свідомості про його неприпустимість. 3 метою реалізації програми, спрямованої на формування у громадян позитивних правових установок, необхідно інтенсивніше застосовувати величезний потенціал засобів масової інформації, які мають не лише правдиво висвітлювати полі- тичну, соціальну і кримінальну обстановку в країні, але і стверджувати моральні правила людського співжиття.

\section{Література}

1. 1,8 мільйона жінок в Україні страждає від фізичного домашнього насильства. Вебсайт. URL: https: / / www. prostir.ua/?news=18-miljona-zhinok-v-ukrajinistrazhdaje-vid-fizychnoho-domashnoho-nasylstva.

2. Щорічна доповідь Уповноваженого Верховної Ради України з прав людини про стан додержання та захисту прав і свобод людини і громадянина в Україні. Вебcaŭm. URL: http://www.univ.kiev.ua/content/upload/2019/ -697223196.pdf.

3. Дерябин С.Д. Криминологический анализ и проблемы предупреждения побоев и истязаний как преступлений против личности : дис. ... канд. юрид. наук. Москва, 1999. 195 с.

4. Антонян Ю.М. Жестокость в нашей жизни. Москва, 1995. 319 C.

5. Антонян Ю.М., Міньковський Г.М. Виховання молоді в побуті. Москва, 1975.37 с.

6. Кім Є.П. Злочинність у сфері сімейно-побутових відносин і їі попередження органами внутрішніх справ : дис. ... канд. юрид. наук. Москва, 1989. 21с.

7. Панфилов Г.А. О содержании понятия бытового преступления. Bопросы борьбы с преступностью. Москва, 1977. Вып. 26. С. 53.

8. Сафуанов Ф.С. Психология криминальной агрессии. Москва. 2003. 300 с..

9. Машинская Н.В. Насилие в семье : дис. ... канд. юрид. наук. Москва, 2001. 21 с.

10. Михайлова Н.Ф. Повседневный стресс в семьях здоровых и больных неврозами. Материалы конгресса по детской психиатрии. Москва, 2001. С. 42-43.

Собко Г. М., кандидат юридичних наук, доцент, викладач кафедри кримінального права та кримінології Одеського державного університету внутрішніх справ 